\title{
Use of PCR for detection of bovine tuberculosis bacillus in milk of positive skin test cows
}

\author{
Uso da PCR para detecção de bacilo da tuberculose bovina \\ em leite de vacas positivas ao teste cutâneo
}

\author{
Ricardo César Tavares CARVALHO ${ }^{1}$; Vinicius Silva CASTRO ${ }^{2}$; \\ Dandara Virginia Guia Semedo FERNANDES ${ }^{2}$; Greika MOURA ${ }^{3}$; Elis Santos SOARES ${ }^{3}$; \\ Eduardo Eustáquio de Souza FIGUEIREDO ${ }^{2,3}$; Vânia Margaret Flosi PASCHOALIN ${ }^{1}$ \\ ${ }^{1}$ Federal University of Rio de Janeiro, Institute of Chemistry, Graduate Program in Food Science, Rio de Janeiro - RJ, Brazil \\ ${ }^{2}$ Federal University of Mato Grosso, Faculty of Nutrition and Food Science and Technology, Cuiabá - MT, Brazil \\ ${ }^{3}$ Federal University of Mato Grosso, Graduate Program in Animal Science, Cuiabá - MT, Brazil
}

\begin{abstract}
The causative agent of bovine tuberculosis (BTB) is Mycobacterium bovis, a bacterium belonging to the M. tuberculosis complex (MTC). The definitive diagnosis is achieved through isolation and identification of $M$. bovis from clinical samples, using a combination of traditional culture and biochemical methods, which is considered the "gold standard". This procedure is cumbersome and time-consuming. We evaluated a PCR assay for the direct detection of MTC DNA in milk of positive skin test cows, using primers that were previously tested and proven reliable to target the IS6110 element. Milk previously seeded with M. bovis was used as the starting material, for standardization of the technique. The procedure involved extracting the DNA by enzymatic lysis (proteinase K and lysozyme), phenol, chloroform, isoamyl alcohol, followed by ethanol precipitation and PCR. The PCR assay allowed us to detect BTB in artificially contaminated milk, with a detection limit of $100 \mathrm{CFU} / \mathrm{mL}$, and was also able to detect the bacillus in 50\% (75/150) of the milk samples tested. This procedure could be used to assist the in vivo diagnosis of BTB, complementing sorological or microbiological tests, becoming an alternative option for epidemiological studies of BTB transmission and preventing contaminated milk from entering the food supply.
\end{abstract}

Keywords: Bovine tuberculosis. Molecular biology. Mycobacterium tuberculosis complex. Milk.

\begin{abstract}
Resumo
O agente causador da tuberculose bovina (BTB) é o Mycobacterium bovis, uma bactéria pertencente ao complexo $M$. tuberculosis (CMT). O diagnóstico definitivo é realizado através do isolamento e identificação de $M$. bovis em amostras clínicas, utilizando uma combinação de cultura bacteriológica e métodos bioquímicos, que são considerados como "padrão de ouro". Entretanto, esses procedimentos são trabalhosos e demorados. No presente estudo, foi avaliado um ensaio de PCR para a detecção direta de DNA de CMT em leite de vacas positivas ao teste cutâneo, utilizando primers previamente testados e comprovadamente confiáveis, para amplificação da região de interesse IS6110. Leite previamente contaminado com M. bovis foi utilizado como material de partida para a padronização da técnica. O procedimento envolveu a extração do DNA por lise enzimática (proteinase K e lisozima), fenol, clorofórmio, álcool isoamílico, seguido de precipitação com etanol e PCR. O ensaio de PCR detectou BTB em leite artificialmente contaminado, com um limite de detecção de $100 \mathrm{UFC} / \mathrm{mL}$, e também foi capaz de detectar o bacilo em 50\% (75/150) das amostras de leite testadas. A técnica de PCR pode ser utilizada para auxiliar o diagnóstico in vivo da BTB, além de complementar os testes sorológicos ou microbiológicos, tornando-se uma alternativa para estudos epidemiológicos da transmissão de BTB, prevenindo que o leite contaminado entre na cadeia de alimentos.
\end{abstract}

Palavras-chave: Tuberculose bovina. Biologia molecular. Complexo Mycobacterium tuberculosis. Leite.

\section{Introduction}

Mycobacterium bovis is a member of the $M$. tuberculosis complex (MTC), a group of species consisting of M. tuberculosis, M. bovis, M. bovis BCG, M. africanum, M. microti, M. caprae, M. pinnipedii e $M$. canetti, all with a high genetic homology. M. bovis is the etiological agent of bovine tuberculosis (BTB),

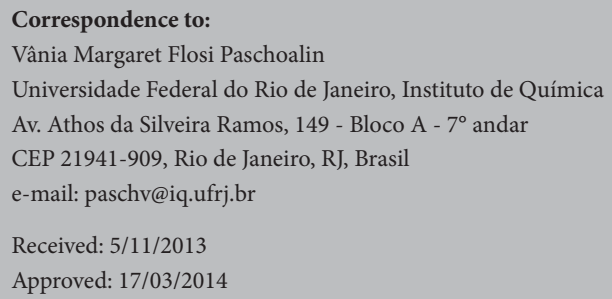


which causes economic and public health problems in many countries. In Brazil, a program for the official control of BTB (National Program for Control and Eradication of Brucellosis and Tuberculosis - PNCEBT) was implemented in 2001, based on a policy of test-and-slaughter (BRASIL, 2004). However, since the beginning of the implementation of PNCEBT, few studies reported the prevalence of the disease, ranging from $0.7 \%$ to $3.3 \%$ (RIBEIRO et al., 2003; BAPTISTA et al., 2004; POLETTO et al., 2004, OLIVEIRA et al., 2007).

In live cattle, bovine tuberculosis infection is usually diagnosed based on delayed hypersensitivity reaction to the intradermal tuberculin test (ITT), a method that may present problems of sensitivity and specificity (FIGUEIREDO et al., 2010). The definitive diagnosis continues to be established through the classical method of isolation and identification of the etiological agent ( $M$. bovis) found in lymph nodes, mainly those associated with the respiratory system, or alternatively, from lungs, by conventional microbiological-biochemical tests. Those methods are laborious and time-consuming (it may take more than 4 weeks to grow the microorganism and an additional 2 weeks to identify it). Several alternative approaches have been evaluated for the rapid and specific diagnosis of tuberculosis, such as histopathology and/or microscopic observation of acid-fast bacilli, or molecular techniques, such as polymerase chain reaction (PCR) assays, which are the most promising for rapid and specific diagnoses in live cattle (SERRANOMORENO et al., 2008; FIGUEIREDO et al., 2010) without the need for isolating pure cultures. Bovine tuberculosis was detected in blood, nasal mucus and milk from ITT positive cows, by amplification of a specie-specific fragment in the genome of $M$. bovis (ROMERO et al., 1999).

Airborne infection is the most common transmission route, and more than $19 \%$ of cattle with BTB shed the mycobacteria, mainly early in the course of the infection (ÁLVAREZ; ESTRADA-
CHÁVEZ; FLORES-VALDEZ, 2009). Studies with molecular markers have shown that infected cattle are a potential source of tuberculosis transmission to humans (SERRANO-MORENO et al., 2008). Milk is an important transmission route, resulting in extralung presentation of the illness (WEDLOCK et al., 2002). For example, in New York City, 35 cases of infection by $M$. bovis were reported from 2001 to 2004, and some of the cases were associated with the consumption of cheese made from non-pasteurized milk, from an endemic area of BTB (CDC, 2005).

Using bacteriological culture methods, it has been calculated that only about $5 \%$ of tuberculin-reacting cattle (TRC) can eliminate M. bovis in milk. In those animals, the occurrence of visible gross lesions in the mammary gland (MG) or supramammary lymph nodes (LN) is less than $0.5 \%$ (SERRANO-MORENO et al., 2008). M. bovis has been isolated from milk from storage tanks, inadequately pasteurized milk, and milk from tuberculin non-reacting cattle (PARDO et al., 2001; LEITE et al., 2003). This situation stresses the need for sensitive and accurate procedures for the rapid identification of the bacteria in milk, to assist in the control of this zoonosis. PCR techniques are highly sensitive and have been successfully used for diagnosing BTB in several types of naturally infected samples such as tissues, blood and nasal exudates (ROMERO et al., 1999; CARDOSO et al., 2009; FIGUEIREDO et al., 2010). Although the PCR for detecting BTB in milk was developed some years ago (ZANINI et al., 1998; JORDÃO JUNIOR et al., 2005; FIGUEIREDO et al., 2008; ZARDEN et al., 2013), it has not been routinely used for disease detection in milk, which could eventually collaborate with BTB control in cattle herds and reduce the possibility of infecting humans through the consumption of contaminated raw milk.

The objective of this study was to select an already established PCR assay (HERMANS et al., 1990) and adapt the methodology for direct detection of members of MTC in the milk of positive skin test cows. 


\section{Materials and Methods}

\section{Bacterial strains and DNA extraction}

Mycobacterium bovis ATCC 19210, M. bovis BCG

INCQS 00062 and M. tuberculosis H37Rv ATCC 27294 were used as positive controls. M. avium ATCC 13950, M. fortuitum ATCC 6841, M. terrae ATCC 15755, M. vacae ATCC 15483, M. xenopi ATCC 33501, $M$. flavescens ATCC 14474, and M. scrofulaceum ATCC 19981 were used as negative controls. Cultures were grown in Lowenstein-Jensen (LJ) or LJ plus sodium pyruvate (LJP) media (M. bovis strains) at $37^{\circ} \mathrm{C}$. DNA was extracted from cultured Mycobacterium spp. through the thermal lysing method (SILVA et al., 2001) and submitted to the PCR under the same conditions used by Hermans et al. (1990), to confirm the sensitivity and specificity of the primers.

\section{Preparation of M. bovis inoculum}

A loopful of $M$. bovis cells (strain IP), collected from a single colony grown on LJP slant, was transferred to a $50 \mathrm{~mL}$ falcon tube containing glass beads (3-5 $\mathrm{mm}$ in diameter) and $10 \mathrm{~mL}$ sterile distilled water. After vigorous stirring by vortex, the supernatant was collected and its cellular density was adjusted to $1.5 \mathrm{x}$ 108 cells/mL, using the MacFarland turbidity standard (KOCAGOZ et al., 1993) and stored at $-20^{\circ} \mathrm{C}$ until use. The exact number of CFU in the stock suspension was determined by colony counting after inoculation of serial 10 fold dilutions of the stock solution $(0.1$ $\mathrm{mL}$ ) onto LJP slants, followed by incubation at $37^{\circ} \mathrm{C}$ for 8 weeks. The CFU obtained was used to adjust the number of cells in the stock cell suspension. Milk from an ITT negative cow $(1.0 \mathrm{~mL})$ was inoculated with increasing amounts of $M$. bovis cells (101-108 CFU/ $\mathrm{mL}$ ) from a standard stock suspension. A total of three samples of each dilution were infected and analyzed.

\section{PCR analyses of samples from naturally infected animals}

A total of 150 adult cows which were reactive to cervical comparative intradermal tuberculin test
(CITT) from various Brazilian dairy herds with a persistent previous history of bovine tuberculosis were used in this study. Milk samples were collected (on the day that PPD was injected) and subjected to bacteriological culture (OIE, 2009) and PCR assay.

\section{Isolation of DNA from raw milk}

DNA was extracted from milk samples by a modification of a QIAamp Blood and Tissue Kit (Qiagen). One milliliter of milk was centrifuged at $10.000 \mathrm{~g}$ for 5 minutes, the pellet was suspended in $180 \mu \mathrm{l}$ of $20 \mathrm{mg} / \mathrm{mL}$ lysozyme in $20 \mathrm{mM}$ Tris $\bullet \mathrm{HCl}, \mathrm{pH}$ 8.0; 2 mM EDTA; and 1.2\% Triton, and incubated for 2 hours at $37^{\circ} \mathrm{C}$ prior to proteinase $\mathrm{K}$ treatment, as recommended by the manufacturer (Qiagen).

\section{Polymerase chain reaction (PCR)}

DNA templates free from contaminants and inhibitors of DNA polymerase were used in amplification reactions, with discrete but significant modifications of the PCR assay previously described. The reaction mix (final volume $50 \mu \mathrm{L}$ ) contained $5 \mu \mathrm{l}$ of $10 \times$ PCR buffer, $200 \mu \mathrm{M}$ of each dNTP, $2.5 \mathrm{U}$ of recombinant Taq polymerase (Invitrogen ${ }^{\circledR}$ ), $0.2 \mu \mathrm{M}$ of primers INS1 (5'-CGTGAGGGCAT CGAGGTGGC-3') and INS2 (5'-GCGTAGGCGTC GGTGACAAA-3'), (HERMANS et al., 1990) $2.0 \mathrm{mM}$ $\mathrm{MgCl} 2$, and $5 \mu \mathrm{L}$ (50 ng) of purified DNA template. Amplification was performed in a Perkin-Elmer 2400 GeneAmp ${ }^{\circledast}$ thermal cycler with the following parameters: $5 \mathrm{~min}$ at $94^{\circ} \mathrm{C}$, followed by 37 cycles of 1 min at $94^{\circ} \mathrm{C}, 1 \mathrm{~min}$ at $68^{\circ} \mathrm{C}$, and $1 \mathrm{~min}$ at $72^{\circ} \mathrm{C}$, and a final elongation step at $72^{\circ} \mathrm{C}$ for $7 \mathrm{~min}$. The annealing time was doubled and the elongation step was included, in order to increase amplification. PCR products (245 bp) were resolved in $2 \%$ agarose gel electrophoresis and stained with ethidium bromide $(10 \mu \mathrm{g} / \mathrm{mL})$.

\section{Results}

The initial conditions of the PCR were standardized and the sensitivity and specificity of the primer pair 
INS1/INS2 were confirmed by using DNA templates prepared from reference strains and from milk artificially contaminated with $M$. bovis at concentrations of 101 to $108 \mathrm{CFU} / \mathrm{ml}$, obtaining specific amplification of the fragment for MTC (245 bp).

In the experiments with serially diluted milk contaminated with $\mathrm{M}$. bovis, the DNA extraction method produced DNA suitable for PCR use. The limit of detection of the PCR assays for M. bovis in milk, as judged by the amplification of the $245 \mathrm{bp}$ fragment, was $100 \mathrm{CFU} / \mathrm{mL}$.

Regarding milk samples naturally contaminated, the PCR assay was able to detect $50 \%$ (75/150) of positive samples, while bacteriological culture was able to identify $25 \%$ (38/150) of $M$. bovis. When performing the comparison of the two techniques, PCR assay was shown to be twice as sensitive as culture.

\section{Discussion}

The PCR assay amplified the expected $245 \mathrm{bp}$ fragment from M. bovis ATCC 19210, M. bovis BCG INCQS 00062 and M. tuberculosis H37Rv. In accordance with the report of Hermans et al. (1990), no amplification was observed for M. avium, M. fortuitum, M. terrae, M. vacae, M. xenopi, $M$. flavescens, and M. scrofulaceum, which are nonMTC species commonly isolated from cattle in Brazil (PARDO et al., 2001; LEITE et al., 2003).

Previously reported PCR results in milk samples are variable, showing detection limits ranging from 80 to $1000 \mathrm{CFU}$ of $M$. bovis in samples inoculated with the bacterium (ZANINI et al., 1998; JORDÃO JÚNIOR et al., 2005; ZUMARRAGA et al., 2005). The estimated detection limit of $100 \mathrm{CFU} / \mathrm{mL}$ is suitable, since an udder infection can result in the shedding of tuberculosis bacilli ranging from 500 to $500,000 \mathrm{CFU}$ /mL of milk (ZANINI et al., 1998).

The application of PCR for the direct detection of pathogens in milk has been limited by the complex composition of the starting material, which may contain inhibitors for PCR amplification. The presence of a divalent cation $(\mathrm{Mg} 2+$ and/or $\mathrm{Ca} 2+)$ can inhibit DNA polymerase, and the presence of proteins and fat globules can obstruct the accessibility of DNA polymerase to the DNA template. Furthermore, the abundance of host epithelial cells in milk could make the bacterial DNA a very small fraction of the total DNA extracted from the sample (ZUMARRAGA et al., 2005). Despite these difficulties, the extraction method reported in the present study produced DNA from spiked milk, which can be used as a template for a PCR assay. The use of the PCR method in spiked milk samples does not guarantee that it would perform equally effectively in the analysis of naturally infected samples. One could expect that in the latter, the interaction between the bacilli and the milk matrix could be more complex, and even that bacilli in milk might have already been killed by mammary macrophages (ZUMARRAGA et al., 2005), and the DNA partially degraded.

For these reasons, the PCR described here was evaluated for detection of BTB in fresh unprocessed milk from CITT-reactive cows. A total of one hundred and fifty raw-milk samples of $50 \mathrm{~mL}$ each were collected on the day of PPD inoculation, and DNA templates were prepared and amplified as described above. Whereas $50 \%$ of the samples were positive for PCR, we could confirm that milk is a potential source of infection for cattle and also for humans, and thus the consumption of untreated milk and dairy products is a public health risk.

Compared with previously described PCR assays in milk samples, our results indicate that an appropriate detection limit of the pathogen in milk was achieved, and this method was able to detect the bacillus directly in naturally infected milk (Table 1). Using milk samples from cows from infected herds, some investigators have not detected any positive animal by PCR (PEREZ et al., 2002), while others targeting for the RvD1-Rv2031c, IS6110 sequence and MPB70 gene have reported amplifications from $2 \%$ to $87 \%$ (VITALE 
Table 1 - Comparison studies using PCR for detection of bovine tuberculosis in milk samples, demonstrating target sequence, limit of detection, percentage of contaminated samples and place of occurrence

\begin{tabular}{lcccc}
\hline Reference & Target Gene & $\begin{array}{c}\text { Detection limit } \\
\text { found for BTB in } \\
\text { milk by PCR }\end{array}$ & $\begin{array}{c}\text { Percentage detection } \\
\text { of BTB in milk by } \\
\text { PCR or PCR variations }\end{array}$ & $\begin{array}{c}\text { Country } \\
\text { of } \\
\text { study }\end{array}$ \\
\hline PRESENT STUDY & IS6110 & $1.0 \times 10^{2} \mathrm{CFU} / \mathrm{mL}$ & $50 \%(75 / 150)$ & Brazil \\
ZARDEN et al., 2013 & IS6110 and RvD1-Rv2031c & NOT SHOWN & $50 \%(4 / 8)$ & Brazil \\
JORDÃO JÚNIOR et al., 2005 & IS6110 and RvD1-Rv2031c & $8.0 \times 10^{1} \mathrm{CFU} / \mathrm{mL}$ & NOT SHOWN & Brazil \\
ZUMARRAGA et al., 2005 & $I S 6110$ & $3.0 \times 100 \mathrm{CFU} / \mathrm{mL}$ & $28 \%(15 / 53)$ & Argentina \\
PEREZ et al., 2002 & IS6110 & NOT SHOWN & $0 \%(0 / 143)$ & Argentina \\
ROMERO et al., 1999 & RvD1-Rv2031c & NOT SHOWN & $2 \%(4 / 184)$ & Colombia \\
ZANINI et al., 1998 & IS1081 & $1.0 \times 10^{3} \mathrm{CFU} / \mathrm{mL}$ & NOT SHOWN & Brazil \\
SERRANO-MORENO et al., 2008 & MPB70 & NOT SHOWN & $18 \%(8 / 44)$ & Mexico \\
VITALE et al., 1998 & IS6110 & NOT SHOWN & $87 \%(47 / 54)$ & Italy \\
RODRIGUEZ et al., 1995 & $R v D 1-R v 2031 c$ & NOT SHOWN & NOT SHOWN & Colombia \\
\hline
\end{tabular}

et al., 1998; ROMERO et al., 1999). Other studies using nested PCR with targets and different techniques (SERRANO-MORENO et al., 2008) also showed that the presence of M. bovis in milk is heterogeneous. The variable PCR results can be explained by bacilli shed from tuberculous cows, depending on the progression of the disease, and may be associated with cellmediated immunity (CMI) (POLLOCK et al., 2001; ROMERO et al., 2006), as well as with epidemiological factors such as viral immunosuppression, metabolic imbalance, corticosteroids and the peripartum condition (DOHERTY et al., 1996; SORDILLO; SHAFER-WEAVER; DEROSA, 1997; PICCININI et al., 2006), resulting in different concentrations of the pathogen in body fluids such as milk. Other explanations to variable PCR results may be related to the amplification conditions, extraction method, sequence and polimorphism of targets used.

Seventy-five (75) of the milk samples taken from CIIT-reactive cows were negative by PCR. This suggested that some periods of bacterial excretion might have been missed, due to the design of the study, which included only one sampling. The intermittent character of bacilli secretion after a short but constant period of post-infection has been documented (MENZIES; NEILL, 2000). The same samples were analyzed through microbiological methods and 25\% $(38 / 150)$ of samples of mycobacterial colonies were isolated. The lack of recovery of Mycobacterium sp. could result from the small number of excreted bacteria, or from the presence of dead or non-viable bacilli through the action of macrophages, or even from the use of the Petroff decontamination method, which might reduce the sensitivity of the culture method compared with PCR (FIGUEIREDO et al., 2010). In this case, the negative results for both PCR and bacteriology indicate that the milk was not contaminated with bacilli.

Although we detected by PCR the DNA of the bacillus in the milk of 75 cows (50\%), the confirmation of viability was observed only for 38 animals (25\%). The occurrence of infected animals that eliminated the bacillus in milk in this study (50\%) is still lower than other studies that have found occurrences of 87\% (VITALE et al., 1998).

\section{Conclusion}

The PCR assay allowed the detection of M. bovis DNA in artificially contaminated milk, with a detection limit of $100 \mathrm{CFU} / \mathrm{mL}$ of milk, and also showed the ability to detect the bacilli of bovine tuberculosis in milk of positive skin test cows. This method could be used to assist the in vivo diagnosis of BTB, complementing intradermal or microbiological tests, becoming an alternative option for epidemiological studies of BTB transmission and preventing contaminated milk from entering the food supply. 


\section{Acknowledgements}

Dr. Leila de Souza Fonseca, Dr. Rafael Duarte and Marlei Gomes da Silva from the Instituto de Microbiologia Paulo de Góes, Universidade Federal do Rio de Janeiro for their support in culturing the bacterial strains. CNPq, FAPEMAT and FAPERJ for financial support.

\section{References}

ÁLVAREZ, A. H.; ESTRADA-CHÁVEZ, C.; FLORES-VALDEZ, M. A. Molecular findings and approaches spotlighting Mycobacterium bovis persistence in cattle. Veterinary Research, v. 40, n. 3, p. 1-16, 2009.

BAPTISTA, F.; MOREIRA, E. C.; SANTOS, W. L. M.; NAVEDA, L. A. B. Prevalência da tuberculose em bovinos abatidos em Minas Gerais. Arquivo Brasileiro de Medicina Veterinária e Zootecnia, v. 56, n. 5, p. 577-580, 2004.

BRASIL. Ministério da Agricultura, Pecuária e Abastecimento. Regulamento Técnico do Programa Nacional de Controle e Erradicação da Brucelose e Tuberculose Animal. Brasília, 2004. $16 \mathrm{p}$

CARDOSO, M. A.; CARDOSO, R. F.; HIRATA, R. D. C.; HIRATA, M. H.; LEITE, C. Q. F.; SANTOS, A. C. B.; SIQUEIRA, V. L. D.; OKANO, W.; ROCHA, N. S.; LONARDONI, M. V. C. Direct detection of Mycobacterium bovis in bovine lymph nodes by PCR. Zoonoses and Public Health, v. 56, n. 8, p. 465-470, 2009.

CENTERS FOR DISEASE CONTROL AND PREVENTION CDC. Human tuberculosis caused by Mycobacterium bovis - New York City, 2001-2004. Morbidity and Mortality Weekly Report, v. 54, n. 24, p. 605-608, 2005.

DOHERTY, M. L.; MONAGHAN, M. L.; BASSETT, H. F.; QUINN, P. J.; DAVIS, W. C. Effect of dietary restriction on cell-mediated immune responses in cattle infected with Mycobacterium bovis. Veterinary Immunology and Immunopathology, v. 49, n. 4, p. 307-320, 1996.

FIGUEIREDO, E. E. S.; SILVA, M. G.; FONSECA, L. S.; SILVA, J. T.; PASCHOALIN, V. M. F. Detecção de Mycobacterium bovis no leite pela reação em cadeia da polimerase seguida de análise de restrição do fragmento amplificado (PRA). Ciência Animal Brasileira, v. 9, n. 4, p. 1023-1033, 2008.

FIGUEIREDO, E. E. S.; CARVALHO, R. C. T.; SILVESTRE, F. G.; LILENBAUM, W.; FONSECA, L. S.; SILVA, J. T.; PASCHOALIN, V. M. F. Detection of Mycobacterium bovis DNA in nasal swabs from tuberculous cattle by a multiplex PCR. Brazilian Journal of Microbiology, v. 41, n. 2, p. 386-390, 2010

HERMANS, P. W.; VAN SOOLINGEN, D.; DALE, J. W.; SCHUITEMA, A. R.; McADAM, R. A.; CATTY, D.; VAN EMBDEN, J. D. Insertion element IS986 from Mycobacterium tuberculosis: a useful tool for diagnosis and epidemiology of tuberculosis. Journal of Clinical Microbiology, v. 28, n. 9, p. 2051-2058, 1990.

JORDÃO JÚNIOR, C. M.; LOPES. F. C. M.; PINTO, M. R. A.; ROXO, E.; LEITE, C. Q. F. Padronização da técnica de PCR na detecção de Mycobacterium bovis diretamente no leite. Alimentos e Nutrição, v. 16, n. 1, p. 51-55, 2005.

KOCAGOZ, T.; YILMAZ, E.; OZKARA, S.; KOCAGOZ, S.; HAYRAN, M.; SACHEDEVA, M.; CHAMBERS, H. F. Detection of Mycobacterium tuberculosis in sputum samples by polymerase

\section{Conflict of Interest Statement}

None of the authors of this paper has a financial or personal relationship with other people or organisations that could inappropriately influence or bias the content of the paper.

chain reaction using a simplified procedure. Journal of Clinical Microbiology, v. 31, n. 6, p. 1435-1438, 1993.

LEITE, C. Q. F.; ANNO, I. S.; LEITE, S. R.; ROXO, E.; MORLOCK, G. P.; COOKSEY, R. C. Isolation and identification of mycobacteria from livestock specimens and milk obtained in Brazil. Memórias do Instituto Oswaldo Cruz, v. 98, n. 3, p. 319-323, 2003

MENZIES, F. D.; NEILL, S. D. Cattle-to-cattle transmission of bovine tuberculosis. The Veterinary Journal, v. 160, n. 2, p. 92 106,2000

ORGANIZACÃO INTERNACIONAL DE EPIZOTIAS - OIE. Terrestrial Manual. 2009. Disponível em: <http://www.oie. int/fileadmin/Home/eng/Health_standards/tahm/2.04.07_ BOVINE_TB.pdf $>$. Acesso em: 29 jan. 2014.

OLIVEIRA, I. A. S.; MELO, H. P. C.; CÂMARA, A.; DIAS, R. V. C.; SOTO-BLANCO, B. Prevalência de tuberculose no rebanho bovino de Mossoró, Rio Grande do Norte. Brazilian Journal of Veterinary Research and Animal Science, v. 44, n. 6, p. 395-400, 2007.

PARDO, R. B.; LANGONI, H.; MENDONCA, L. J. P.; CHI, K. D. Isolation of Mycobacterium spp. in milk from cows suspected or positive to tuberculosis. Brazilian Journal of Veterinary Research and Animal Science, v. 38, n. 6, p. 284-287, 2001.

PEREZ, A.; RENIERO, A.; FORTEIS, A.; MEREGALLI, S. LOPEZ, B.; RITACCO, V. Study of Mycobacterium bovis in milk using bacteriological methods and the polymerase chain reaction. Revista Argentina de Microbiología, v. 34, n. 1, p. 45-51, 2002.

PICCININI, R.; LUZZAGO, C.; FRIGERIO, M.; DAPRA, V.; LIANDRIS, E.; ZECCONI, A. Comparison of blood nonspecific immune parameters in bovine virus diarrhoea virus (BVDV) persistently infected and in immune heifers. Journal of Veterinary Medicine - Series B - Infectious Diseases and Veterinary Public Health, v. 53, n. 2, p. 62-77, 2006.

POLETTO, R.; KREUTZ, L. C.; GONZÁLES, J. C.; BARCELLOS, L. J. G. Prevalência de tuberculose, brucelose e infecções víricas em bovinos leiteiros do município de Passo Fundo - RS. Ciência Rural, v. 34, n. 2, p. 595-598, 2004.

POLLOCK, J. M.; McNAIR, J.; WELSH, M. D.; GIRVIN, R. M.; KENNEDY, H. E.; MACKIE, D. P.; NEILL, S. D. Immune responses in bovine tuberculosis. Tuberculosis, v. 81, n. 1-2, p. 103-107, 2001.

RIBEIRO, A. R. P.; LOBATO, F. C. F.; ABREU, V. L. V.; FARIA, E. S.; SILVA, J. A. Prevalência de tuberculose e brucelose bovina no município de Ilhéus. Arquivo Brasileiro de Medicina Veterinária e Zootecnia, v. 55, n. 1, p. 120-122, 2003.

RODRIGUEZ, J. G.; MEJIA, G. A.; PORTILlO, P. D.; PATARROYO, M. E.; MURILLO, L. A. Species-specific identification of Mycobacterium bovis by PCR. Microbiology, v. 141, n. 9, p. 2131-2138, 1995.

ROMERO, R. E.; GARZON, D. L.; MEJIA, G. A.; MONROY, W.; PATARROYO, M. E.; MURILLO, L. A. Identification of 
Mycobacterium bovis in bovine clinical samples by PCR speciesspecific primers. Canadian Journal of Veterinary Research, v. 63, n. 2, p. 101-106, 1999.

ROMERO, T. A.; ARRIAGA, C.; GUEVARA, V. J.; GARCIA, S. J. A.; TORRES, L. R. A.; ESTRADA-CHÁVEZ, C. Confirmación de la excreción de Mycobacterium bovis en exudados nasales mediante PCR anidada en un hato lechero. Veterinaria México, v. 37, n. 1, p. 137-143, 2006.

SERRANO-MORENO, B. A.; ROMERO, T. A.; ARRIAGA, C.; TORRES, R. A.; PEREIRA-SUÁREZ, A. L.; GARCIA-SALAZAR, J. A.; ESTRADA-CHÁVEZ, C. High frequency of Mycobacterium bovis DNA in colostra from tuberculous cattle detected by nested PCR. Zoonoses and Public Health, v. 55, n. 5, p. 258-266, 2008.

SILVA, C. F.; UEKI, M. S. Y.; GEIGER, P. D. C.; LEÃO, S. C. Hsp65 PCR-restriction enzyme analysis (PRA) for identification of mycobacteria in the clinical laboratory. Revista do Instituto de Medicina Tropical de São Paulo, v. 43, n. 1, p. 25-28, 2001.

SORDILLO, L. M.; SHAFER-WEAVER, K.; DEROSA, D. Immunobiology of the mammary gland. Journal of Dairy Science, v. 80, n. 8, p. 1851-1865, 1997.
WEDLOCK, D. N.; SKINNER, M. A.; DE LISLE, G. W.; BUDDLE, B. M. Control of Mycobacterium bovis infections and the risk to human populations. Microbes and Infection, v. 4, n. 4, p. 471480, 2002.

ZANINI, M. S.; MOREIRA, E. C.; LOPES, M. T. P.; SALAS, C. E. Detection of Mycobacterium bovis in milk by polymerase chain reaction. Journal of Veterinary Medicine - Series B - Infectious Diseases and Veterinary Public Health, v. 45, n. 8, p. 1129-1132, 1998.

ZARDEN, C. F. O.; MARASSI, C. D.; FIGUEIREDO, E. E. S.; LILENBAUM, W. Mycobacterium bovis detection from milk of negative skin test cows. Veterinary Record, v. 172, n. 5, p. 130, 2013.

ZUMARRAGA, M. J.; MEICKLE, V.; BERNARDELLI, A.; ABDALA, A.; TARABLA, H.; ROMANO, M. I.; CATALDI, A. Use of touch-down polymerase chain reaction to enhance the sensitivity of Mycobacterium bovis detection. Journal of Veterinary Diagnostic Investigation, v. 17, n. 3, p. 232-238, 2005. 